\title{
Impaired regulation of the TNF- $\alpha$ converting enzyme/tissue inhibitor of metalloproteinase 3 proteolytic system in skeletal muscle of obese type 2 diabetic patients: a new mechanism of insulin resistance in humans
}

\author{
A. Monroy - S. Kamath - A. O. Chavez • V. E. Centonze - M. Veerasamy • \\ A. Barrentine - J. J. Wewer • D. K. Coletta - C. Jenkinson • R. M. Jhingan • \\ D. Smokler • S. Reyna • N. Musi • R. Khokka • M. Federici • D. Tripathy • \\ R. A. DeFronzo - F. Folli
}

Received: 7 November 2008 / Accepted: 11 June 2009 / Published online: 25 July 2009

(C) Springer-Verlag 2009

\begin{abstract}
Aims/hypothesis TNF- $\alpha$ levels are increased in obesity and type 2 diabetes. The regulation of TNF- $\alpha$ converting enzyme (TACE) and its inhibitor, tissue inhibitor of metalloproteinase 3 (TIMP3), in human type 2 diabetes is unknown.

Methods We examined TACE/TIMP3 regulation: (1) in lean and obese normal glucose tolerant (NGT) individuals
\end{abstract}

A. Monroy, S. Kamath, and A. O. Chavez contributed equally to this study.

Electronic supplementary material The online version of this article (doi:10.1007/s00125-009-1451-3) contains supplementary material, which is available to authorised users.

A. Monroy $\cdot$ S. Kamath $\cdot$ A. O. Chavez $\cdot$ M. Veerasamy $\cdot$

A. Barrentine $\cdot$ D. K. Coletta $\cdot$ C. Jenkinson $\cdot$ R. M. Jhingan •

S. Reyna $\cdot$ N. Musi $\cdot$ D. Tripathy $\cdot$ R. A. DeFronzo $\cdot$ F. Folli $(\bowtie)$

Department of Medicine/Division of Diabetes,

University of Texas Health Science Center at San Antonio,

7703 Floyd Curl Drive, MC 7886,

San Antonio, TX 78229-3900, USA

e-mail: folli@uthscsa.edu

V. E. Centonze $\cdot$ J. J. Wewer

Cellular and Structural Biology Department,

University of Texas Health Science Center at San Antonio,

San Antonio, TX, USA

D. Smokler $\cdot$ R. Khokka

Ontario Cancer Institute,

Toronto, ON, Canada

M. Federici

Department of Internal Medicine, University of Rome

'Tor Vergata',

Rome, Italy and in type 2 diabetes patients; (2) following $6 \mathrm{~h}$ of lipid/ saline infusion in NGT individuals; and (3) in cultured human myotubes from lean NGT individuals incubated with palmitate. Insulin sensitivity was assessed by a euglycaemic clamp and TACE/TIMP3 was evaluated by confocal microscopy, RT-PCR, western blotting and an in vitro activity assay. Circulating TNF- $\alpha$, TNF- $\alpha$-receptor 1 (TNFR1), TNF- $\alpha$-receptor 2 (TNFR2), IL-6 receptor (IL$6 \mathrm{R}$ ), vascular cell adhesion molecule (VCAM) and intercellular adhesion molecule (ICAM) levels were evaluated. Results TIMP3 levels were reduced and TACE enzymatic activity was increased in type 2 diabetes skeletal muscle. TACE expression, and TACE, TNF- $\alpha$, TNFR1 and IL-6R levels were increased in type 2 diabetes, and positively correlated with insulin resistance. A $6 \mathrm{~h}$ lipid infusion into NGT individuals decreased insulin-stimulated glucose metabolism by $25 \%$ with increased TACE, decreased expression of the gene encoding TIMP3 and increased IL$6 \mathrm{R}$ release. Palmitate induced a dramatic reduction of TIMP3 and increased the TACE/TIMP3 ratio in cultured myotubes.

Conclusions/interpretation TACE activity was increased in skeletal muscle of obese type 2 diabetes patients and in lipid-induced insulin resistance. We propose that dysregulation of membrane proteolysis by TACE/TIMP3 of TNF- $\alpha$ and IL-6R is an important factor for the development of skeletal muscle insulin resistance in obese type 2 diabetes patients by a novel autocrine/paracrine mechanism.

Keywords Human type 2 diabetes mellitus . Insulin resistance $\cdot$ TACE $\cdot$ TIMP3 


\begin{tabular}{|c|c|}
\hline \multicolumn{2}{|c|}{ Abbreviations } \\
\hline $\mathrm{ACC}$ & Acetyl-CoA carboxylase \\
\hline ADAM-17 & $\begin{array}{l}\text { A disintegrin and metallopeptidase } \\
\text { domain } 17\end{array}$ \\
\hline AMPK & 5'-AMP-activated protein kinase \\
\hline $\mathrm{Ch}$ & Channel \\
\hline ERK $1 / 2$ & $\begin{array}{l}\text { Extracellular signal-regulated kinases } 1 \\
\text { and } 2\end{array}$ \\
\hline GAPDH & Glyceraldehyde 3-phosphate dehydrogenase \\
\hline GFP & Green fluorescent protein \\
\hline HOMA-IR & $\begin{array}{l}\text { Homeostasis model assessment of insulin } \\
\text { resistance }\end{array}$ \\
\hline ICA & Intensity correlation analysis \\
\hline $\begin{array}{l}\text { IKK-alpha/ } \\
\text { beta }\end{array}$ & I kappa-B kinase alpha/beta \\
\hline IL-6R & IL-6 receptor \\
\hline IR & Insulin receptor \\
\hline $\operatorname{IR} \alpha$ & IR alpha subunit \\
\hline JNK & Jun $\mathrm{N}$-terminal kinase \\
\hline$M$ & Insulin-stimulated glucose disposal rate \\
\hline NGT & Normal glucose tolerant \\
\hline PDM & Product of differences of the mean \\
\hline $\mathrm{Rr}$ & Pearson's co-localisation coefficient \\
\hline sICAM & Soluble intercellular adhesion molecule-1 \\
\hline sIL-6R & Soluble IL-6 receptor \\
\hline sTNFR1 & Soluble TNF- $\alpha$ receptor 1 \\
\hline sTFNR2 & Soluble TNF- $\alpha$ receptor 2 \\
\hline sVCAM & Soluble vascular cell adhesion molecule- 1 \\
\hline TACE & TNF- $\alpha$ converting enzyme \\
\hline TIMP3 & Tissue inhibitor of metalloproteinase 3 \\
\hline TNFR1 & TNF- $\alpha$ receptor 1 \\
\hline TNFR2 & TNF- $\alpha$ receptor 2 \\
\hline
\end{tabular}

\section{Introduction}

Insulin resistance is the hallmark of obesity and type 2 diabetes and is a major risk factor for cardiovascular disease [1]. Obesity and type 2 diabetes are characterised by a lowgrade inflammation state that may also contribute to the increased risk of cardiovascular disease in these patients $[2$, 3]. TNF- $\alpha$ is a pro-inflammatory cytokine that was first linked to insulin resistance by Hotamisligil et al. [4-7] in the $o b / o b$ mouse, a model of obesity and type 2 diabetes $[8$, 9]. Although the role played in insulin resistance by TNF- $\alpha$ is well established in animals, its contribution to the development of impaired insulin action in humans is controversial $[4,10,11]$. While patients with type 2 diabetes and obesity have increased plasma levels of inflammatory cytokines, e.g. TNF- $\alpha$ and IL-6 [12-14], the infusion of TNF- $\alpha$-neutralising antibody does not signifi- cantly improve insulin sensitivity in obese type 2 diabetes patients [15].

Pro-TNF- $\alpha$ is expressed as a $26 \mathrm{kDa}$ membrane-bound protein and processed into a $17 \mathrm{kDa}$ soluble form, TNF- $\alpha$, that is released from the cell surface by the action of a disintegrin and metalloproteinase (ADAM-17) also called TNF- $\alpha$ converting enzyme (TACE) [16, 17]. Tissue inhibitor of matrix metalloproteinase 3 (TIMP3) controls TNF- $\alpha$ levels in vivo [18]. Among the four TIMPs, only TIMP3 binds to the extracellular matrix and contains an amino acid sequence (PFG) required for TACE inhibition [19]. It has been previously shown that Timp3 acts as a modifier gene whereby its deficiency contributes to the onset of diabetes in insulin receptor (IR) heterozygous mice, supported by the development of glucose intolerance and hyperinsulinaemia in Insr and Timp 3 doubleheterozygous mice [20]. Short-term in vivo inhibition of TACE results in a marked reduction of hyperglycaemia and vascular inflammation in this model of insulin resistance and type 2 diabetes. While Tace (also known as Adam17) heterozygous mice are partially protected from diabetes and obesity induced by high-fat diet, Tace homozygous mice show a lean hypermetabolic phenotype [20-22].

Here, we have explored the role of TACE and TIMP 3 in mediating insulin resistance in non-diabetic obese and type 2 diabetes individuals, and have tested the effects of $6 \mathrm{~h}$ lipid infusion, a treatment known to induce insulin resistance, on the regulation of TACE/TIMP3 in normal individuals.

\section{Methods}

Participants Fourteen lean and 14 obese individuals with normal oral $(75 \mathrm{~g})$ glucose tolerance and 14 type 2 diabetes patients were studied [23]. Their clinical and laboratory characteristics are shown in the Table 1. BMI was $<25 \mathrm{~kg} / \mathrm{m}^{2}$ in all lean participants. There was no evidence of major organ disease (except diabetes) based upon history, physical examination, clinical chemistry, urinalysis and ECG. Weight was stable for at least 3 months prior to the study and, other than oral glucoselowering drugs (metformin or glibenclamide [known as glyburide in the USA and Canada]), no participant was taking medication. Fasting blood samples were taken from an antecubital vein to determine $\mathrm{HbA}_{1 \mathrm{c}}$. Insulin sensitivity was assessed with a euglycaemic-hyperinsulinaemic (80 $\mathrm{mU} \mathrm{m}^{-2} \mathrm{~min}^{-1}$ ) clamp [24] or by the homeostatic model assessment of insulin resistance index (HOMA-IR) [25]. In each participant, following a 10-12 h overnight fast, a percutaneous biopsy was obtained from the vastus lateralis muscle under local anaesthesia using a Bergström needle. 
In a separate group, 12 normal glucose tolerant (NGT) individuals (Electronic supplementary material [ESM] Table 1) were infused in random order with either lipid (Lyposin III (Hospira, Inc., Lake Forest, IL, USA), 20\% (wt/vol.) triacylglycerol emulsion) or $0.9 \%$ (wt/vol.) saline solution at a rate of $60 \mathrm{ml} / \mathrm{h}$ for $6 \mathrm{~h}$. Percutaneous vastus lateralis muscle biopsies were obtained from these individuals before and after the $6 \mathrm{~h}$ infusion. Finally, after the second biopsy was taken, a $2 \mathrm{~h}$ euglycaemic insulin (80 $\mathrm{mU} \mathrm{m}^{-2} \mathrm{~min}^{-1}$ ) clamp was performed on all participants (ESM Fig. 1). Each participant gave written informed consent and all studies were previously approved by the University of Texas Health Science Center Institutional Review Board.

Confocal microscopy Confocal microscopy experiments were carried out as previously described [26, 27] and as detailed in the ESM Methods.

Subcellular fractionation Subcellular fractionation was carried out with human skeletal muscle by differential centrifugation as described $[28,29]$ with minor modifications, as detailed in ESM Methods (Fig. 1a).

RNA extraction and real-time quantitative $R T-P C R$ analysis Total RNA was extracted from human skeletal muscle, as detailed in ESM Methods. RNA expression of TACE, TIMP3, IR (also known as INSR), IRS-1 (also known as IRS1) and Akt (also known as Akt1) (gene assays on demand Hs00234224_m1, HS00165949_m1, Hs00961557_m1, Hs00178563 and Hs99999145_m1, respectively) was measured by TaqMan real-time RT-PCR using an ABI PRISM 7900Ht System (Applied Biosystems, Foster City, CA, USA) and normalised to $18 \mathrm{~S}$ rRNA selected as an endogenous control. Each reaction was carried out in duplicate. Efficiency of each probe was determined by serial dilutions of RNA skeletal muscle standard (Ambion, Austin, TX, USA) and analysis performed by the $2^{-\Delta \Delta \mathrm{C}_{\mathrm{t}}}$ method.

ELISA A sandwich ELISA method was performed using anti-mouse antibodies conjugated to horseradish peroxidase, for human soluble TNF- $\alpha$ receptor 1 (sTNFR1), human soluble TNF- $\alpha$ receptor 2 (sTNFR2), human soluble IL-6 receptor (sIL-6R), human soluble vascular cell adhesion molecule-1 (sVCAM), and human soluble intercellular adhesion molecule-1 (sICAM) (R\&D Systems, Minneapolis, MN, USA) according to the manufacturer's instructions. The minimum detectable concentration was $0.77 \mathrm{pg} / \mathrm{ml}$ for sTNFR1, $6.5 \mathrm{pg} / \mathrm{ml}$ for sIL-6R, $0.6 \mathrm{pg} / \mathrm{ml}$ for sTNFR2, $0.35 \mathrm{ng} / \mathrm{ml}$ for sICAM and $0.6 \mathrm{ng} / \mathrm{ml}$ for sVCAM. The intra-assay and inter-assay $\mathrm{CV}$ values were $4.4 \%$ and $6.1 \%$ for sTNFR $1,4.5 \%$ and $5.1 \%$ for sIL-6R,
$3.5 \%$ and $4.0 \%$ for sTNFR $2,4.8 \%$ and $10.1 \%$ for sICAM, and $3.1 \%$ and $7.0 \%$ for SVCAM, respectively. Sera were diluted before assay.

Western blotting Proteins were separated by SDS-PAGE, transferred to nitrocellulose membrane with $5 \%$ (wt/vol.) non-fat dried milk (Bio-Rad, Hercules, CA, USA) in TRISbuffered saline $(20 \mathrm{mmol} / \mathrm{l}$ TRIS [pH 7.4], $150 \mathrm{mmol} / \mathrm{l}$ $\mathrm{NaCl}$ and $0.02 \%$ (vol./vol.) Tween-20) and probed with primary antibodies to TACE and TIMP3 (Santa Cruz Biotechnology, Santa Cruz, CA, USA), and to pro-TNF- $\alpha$, TNF- $\alpha, \beta$-actin, alpha subunit of IR (IR $\alpha$ ), glyceraldehyde 3-phosphate dehydrogenase (GAPDH), AKT, phosphoAKT (Ser 473), 5'-AMP-activated protein kinase (AMPK), phospho-AMPK and phospho-acetyl-CoA carboxylase (all antibodies were from Cell Signaling Technology, Danvers, MA, USA) followed by secondary antibodies as appropriate, and visualised by enhanced chemiluminescence, as described [30].

TACE activity assay TACE activity was determined by the cleavage of the 12 residue peptide that spans residues Ala76 to Val-87 in pro-TNF- $\alpha$ (ADAM-17 substrate IV) as previously described [31] and detailed in ESM Methods.

Generation of primary myotubes Primary skeletal muscle cells were grown from satellite cells obtained from muscle tissue as previously described $[32,33]$. All donors were lean and were NGT. Human myotubes were treated with fatty acid-free BSA or 200 and $400 \mu \mathrm{mol} / 1$ palmitate for $4 \mathrm{~h}$. Palmitate was mixed with acid-free BSA at a 5:1 palmitate/ BSA ratio. After treatment, cells were lysed in lysis buffer (20 mmol/1 TRIS, pH 7.5, $5 \mathrm{mmol} / 1 \mathrm{EDTA}, 10 \mathrm{mmol} /$ $1 \mathrm{Na}_{3} \mathrm{PO}_{4}, 100 \mathrm{mmol} / 1 \mathrm{NaF}, 2 \mathrm{mmol} / 1 \mathrm{Na}_{3} \mathrm{VO}_{4}, 1 \%$ (vol./ vol.) NP-40, $10 \mu \mathrm{mol} / \mathrm{l}$ leupeptin, $3 \mathrm{mmol} / \mathrm{l}$ benzamidine, $10 \mu \mathrm{g} / \mathrm{ml}$ aprotinin and $1 \mathrm{mmol} / \mathrm{l}$ phenylmethylsulfonyl fluoride). TIMP3, TACE, IR and $\beta$-actin protein content were measured by western blotting and densitometric analysis using a Bio-Rad GS800 (Bio-Rad, Hercules, CA, USA) densitometer as previously described [31, 32].

Adenovirus infection Adenoviruses expressing green fluorescent protein (GFP) only or GFP and TACE (Vector Biolabs, Philadelphia, PA, USA) were used to infect myotubes as described in ESM Methods.

Statistical analysis Comparison between groups and association between variables were performed using Student's $t$ test, one-way ANOVA, two-way ANOVA and Pearson's correlation coefficient $(r)$ where appropriate (SPSS v.13 for Windows; SPSS, Chicago, IL, USA). Data are expressed as means \pm SEM. $p<0.05$ was considered statistically significant. 


\section{Results}

TNF- $\alpha$, TACE, TIMP3 and IR distribution in human skeletal muscle Fluorescence immunostaining and quantification by confocal microscopy were used to assess the abundance and subcellular localisation of TACE, TIMP3, TNF- $\alpha$ and IR in human skeletal muscle. TACE and IR distribution displayed a punctate staining pattern throughout the tissue but with a predominant localisation on the surface sarcolemma (ESM Figs 2a and 3a for TACE; ESM Figs $2 \mathrm{c}$ and $4 \mathrm{~b}$ for IR), whereas TIMP3 showed a diffuse and reticular localisation pattern (ESM Fig. 2b). TNF- $\alpha$ was localised as a thin layer on the plasma membrane surface (ESM Figs 3b and 4a). Secondary antibodies alone did not show any specific staining, indicating the specificity of the pattern observed (data not shown). Merged images showed regions with co-localisation of TNF- $\alpha$, TACE, TIMP3 and IR on the sarcolemmal surface (ESM Figs 2d, $3 \mathrm{c}$, and $4 \mathrm{c}$ ). To confirm the co-localisation pattern observed, we carried out quantitative analysis of co-localised staining in the images. Application of this method resulted in positive values for the product of differences of the mean (PDM) and Pearson's coefficient ( $\mathrm{Rr}$ ) in each pair analysed (IR-TACE 0.42; TACE-TIMP3 0.74; IR-TIMP3 0.56; TACE-TNF- $\alpha$ 0.38; and IR-TNF- $\alpha 0.63$ ), with intensity correlation analysis (ICA) exhibiting right-skewed plots indicative of partial co-localisation. Channel co-localisation indicated that TACE signal resides in a subset of the IR and TIMP3 signal (ESM Fig. 2h, j), IR is a subset of the TIMP3 and TNF- $\alpha$ signal (ESM Figs $2 \mathrm{~m}$ and $4 \mathrm{~g}$ ), and TNF- $\alpha$ is a subset of TACE and IR signal (ESM Figs $3 g$ and $4 f$ ). The overlapping patterns of abundance of IR, TACE, TNF- $\alpha$ and TIMP3 in human skeletal muscle suggest the possibility that TNF- $\alpha$ binds TNF- $\alpha$ receptor (TNFR) 1 or 2 and this may result in phosphorylation of serine/threonine kinases (JNK, IKKalpha/beta and ERK 1/2), which in turn negatively regulates insulin signalling at the skeletal muscle plasma membrane and this could directly inhibit IR signalling and, thus, glucose disposal by the muscle, in a paracrine fashion.

TACE and TIMP3 intracellular distribution in human skeletal muscle To define TACE and TIMP3 subcellular localisation, we performed human skeletal muscle subcellular fractionation (Fig. 1a) and immunoblot analysis in each of three fractions (internal membrane, cytosol and plasma membrane), and in total homogenate. TIMP3 was present in all three subcellular compartments although enriched in plasma membrane (Fig. 1c), while TACE was found to be highly enriched in plasma membrane (Fig. 1b). In order to define the relative enrichment obtained during the subcellular fractionation procedure, we performed western blotting experiments with anti-GAPDH antibodies as well as with antibodies to IR $\alpha$. GAPDH, a cytosolic protein, was virtually absent in the plasma membrane fraction (ESM Fig. 5a), while IR $\alpha$ was enriched more than twofold in the plasma membrane fraction (ESM Fig. 5b). Furthermore, Coomassie staining of two separate subcellular fractionation experiments demonstrated that the protein band compositions of the three subcellular fractions that we examined, i.e. plasma membranes, internal membranes and cytosol, were highly reproducible and markedly different from each other as well as from the total homogenate (ESM Fig. 5c).

TACE, TIMP3, pro-TNF- $\alpha$ and TNF- $\alpha$ expression in human skeletal muscle from NGT individuals and type 2 diabetes patients We analysed expression of TACE in human skeletal muscle by quantitative RT-PCR amplification of RNA from lean NGT and obese NGT individuals and obese type 2 diabetes patients (Table 1$)$. A significant $(p<0.01)$ increase in $T A C E$ expression in type 2 diabetes patients $(2.59 \pm 0.65)$ compared with lean NGT individuals $(1.00 \pm$ 0.26) was observed (Fig. 2a). A modest but statistically insignificant increase in $T A C E$ expression was also observed in obese NGT individuals (1.52 \pm 0.31$)$. TACE RNA expression was positively correlated with insulin resistance, measured as HOMA-IR $(r=0.549, p<0.001$; data not shown) and was inversely correlated with insulinstimulated glucose disposal rate $(M)$ during the euglycaemic insulin clamp, $r=-0.369, p<0.05$ (data not shown). TACE RNA expression also correlated with BMI $(r=0.411$, $p=0.02$ ), suggesting a positive association with obesity and an inverse relationship with insulin sensitivity. We next determined if the increase in TACE RNA expression was paralleled by a rise in protein levels; we performed western blots from skeletal muscle homogenates from lean NGT and obese NGT individuals and obese type 2 diabetes patients. Densitometric analysis of the western blots showed no significant increase in TACE levels between NGT and type 2 diabetes individuals (Fig. 2b). Because of the inhibitory action of TIMP3 over TACE and to examine further the regulation of TACE production in type 2 diabetes, we quantified the abundance of TIMP3 in type 2 diabetic, lean NGT and obese NGT individuals. We found a $70 \%$ reduction in TIMP3 levels in skeletal muscle of type 2 diabetes compared with lean NGT participants $(p<0.01)$ (Fig. 2c) by western blotting; obese NGT individuals showed a $40 \%$ of decrease in TIMP3 levels vs lean NGT individuals. We then quantified the abundance of proTNF- $\alpha$ as well as TNF- $\alpha$ in the skeletal muscle of lean, obese and type 2 diabetic participants. We observed a significant increase in the levels of pro-TNF- $\alpha$ as well as TNF- $\alpha$ in the skeletal muscle of type 2 diabetic patients (Fig. 2d, e). $\beta$-Actin levels were similar in the three study groups (Fig. 2f). 
a

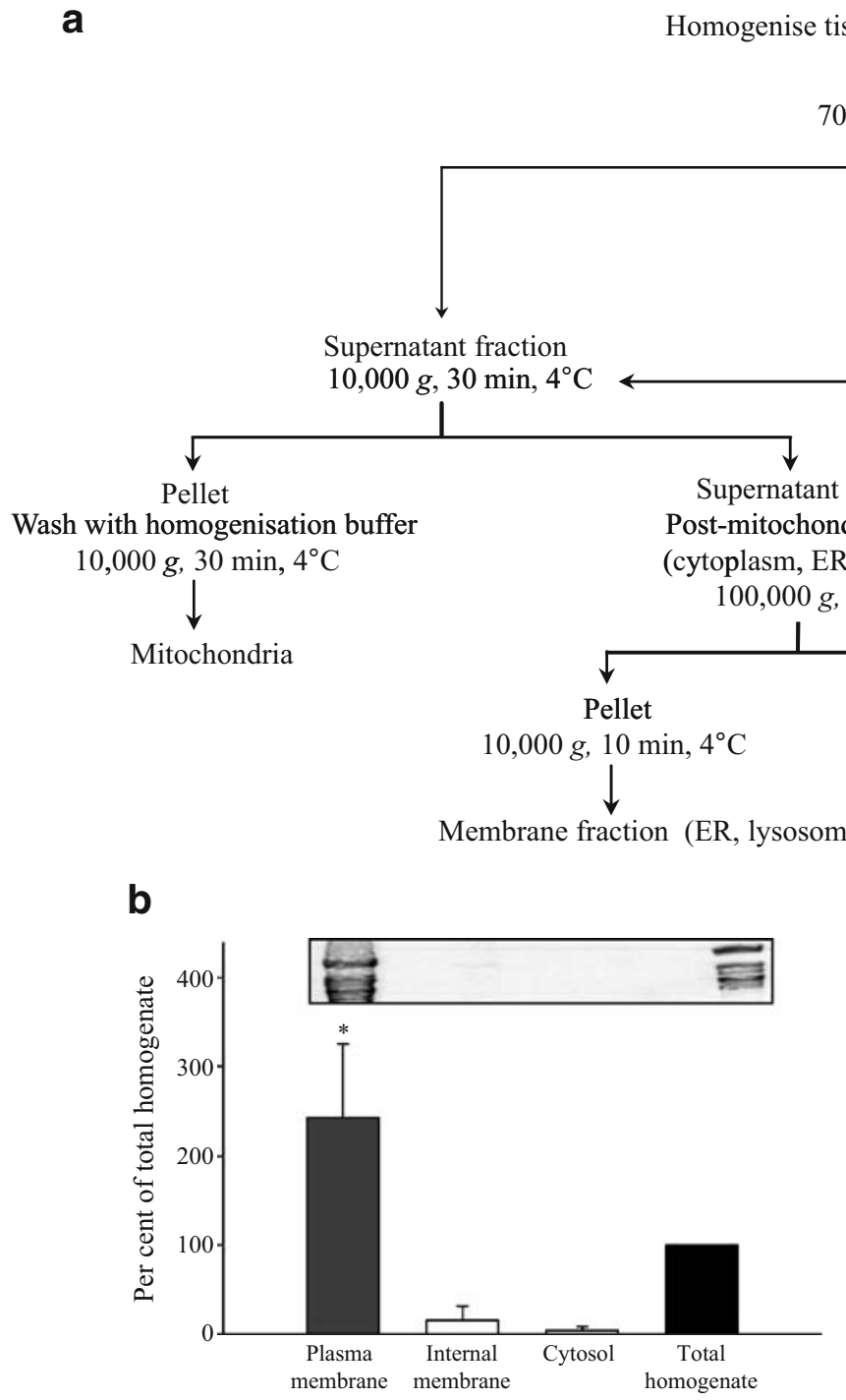

Fig. 1 Subcellular distribution of TACE and TIMP3 in skeletal muscle of NGT individuals. a Subcellular fractionation method outline. b, c Immunoblot analysis of human skeletal muscle

In vitro assay of TACE activity in skeletal muscle in lean and obese participants and type 2 diabetes patients To investigate whether decreased TIMP3 levels resulted in increased enzymatic TACE activity in skeletal muscle homogenates, we used a fluorogenic peptide substrate assay. Figure $3 \mathrm{a}, \mathrm{b}$ demonstrates a linear increase in human skeletal muscle protein and TACE activity. In skeletal muscle from type 2 diabetes patients TACE activity was increased by $33 \%$ compared with NGT individuals $(p<0.05)$; no difference was observed between lean NGT and obese NGT individuals (Fig. 3c, d). Interestingly, TACE activity correlated positively with NEFA concentration $\left(r=0.460, r^{2}=0.211, p<0.05\right)$ (Fig. 3e) and correlated negatively with $M$ value (insulin sensitivity) $\left(r=-0.471, r^{2}=0.222, p<0.05\right)$ (Fig. 3f).
C

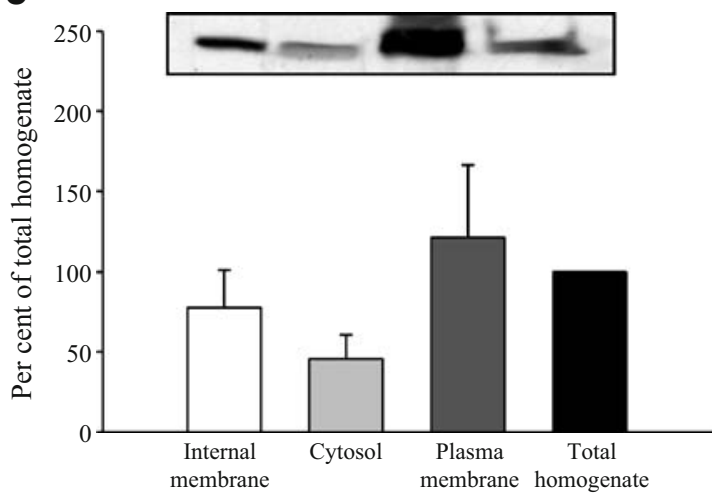

subcellular fractions employing anti-TACE (b) and anti-TIMP3 (c) antibodies. ${ }^{*} p<0.05(n=3-4$ for $\mathbf{b}$ and $\mathbf{c})$. Data are means \pm SEM. ER, endoplasmic reticulum

Determination of soluble circulating TACE substrates In addition to shedding pro-TNF- $\alpha$ as TNF- $\alpha$, TACE converts several other membrane-bound proteins to their soluble forms. To evaluate the effect of increased TACE levels on its substrates, TNF- $\alpha$, circulating TNFR1, TNFR2, IL-6R and cell-surface adhesion molecule (intercellular adhesion molecule-1 [sICAM] and vascular cell adhesion molecule-1 [sVCAM]) levels were measured in serum using an ELISA. TNF- $\alpha$ levels were significantly increased in type 2 diabetic patients compared with obese NGT as well as lean NGT individuals (Table 1). sTNFR1 was significantly increased in type 2 diabetes vs NGT lean $(p<0.05)$ and NGT obese individuals $(p<0.05)$ (Fig. 3g). sTNFR1 levels were inversely and significantly correlated with insulin sensitivity, measured as insulin-stimulated glucose disposal rate $(M)$ 
Table 1 Clinical, laboratory and metabolic characteristics of participants

Data are means \pm SEM ${ }^{\mathrm{a}} p<0.05,{ }^{\mathrm{b}} p<0.001$ vs lean; ${ }^{\mathrm{c}} p<0.05,{ }^{\mathrm{d}} p<0.001$ vs obese $\mathrm{M}$, male; F, female

\begin{tabular}{llll}
\hline Characteristic & Lean & Obese & Type 2 diabetes \\
\hline Sex $(\mathrm{M} / \mathrm{F})$ & $7 / 7$ & $7 / 7$ & $7 / 7$ \\
Age $($ years) & $37 \pm 3$ & $39 \pm 2$ & $42 \pm 3$ \\
$\mathrm{BMI}\left(\mathrm{kg} / \mathrm{m}^{2}\right)$ & $22.3 \pm 0.5$ & $30.1 \pm 0.7^{\mathrm{b}}$ & $31.9 \pm 1.8^{\mathrm{b}}$ \\
$\mathrm{HbA}_{1 \mathrm{c}}(\%)$ & $5.1 \pm 0.1$ & $5.2 \pm 0.1$ & $8.4 \pm 0.3^{\mathrm{b}, \mathrm{d}}$ \\
$M$ value $\left(\mu \mathrm{mol} \mathrm{kg}{ }^{-1} \mathrm{~min}^{-1}\right)$ & $644 \pm 50$ & $411 \pm 28^{\mathrm{b}}$ & $189 \pm 22^{\mathrm{b}, \mathrm{d}}$ \\
Total cholesterol $(\mathrm{mmol} / \mathrm{l})$ & $4.6 \pm 0.2$ & $4.4 \pm 0.2$ & $5.0 \pm 0.2^{\mathrm{d}}$ \\
LDL-cholesterol $(\mathrm{mmol} / \mathrm{l})$ & $2.9 \pm 0.2$ & $2.9 \pm 0.2$ & $2.8 \pm 0.2^{2}$ \\
HDL-cholesterol $(\mathrm{mmol} / \mathrm{l})$ & $1.3 \pm 0.1$ & $1.1 \pm 0.1$ & $0.9 \pm 0.1^{\mathrm{b}}$ \\
Triacylglycerol $(\mathrm{mmol} / \mathrm{l})$ & $1.0 \pm 0.3$ & $1.1 \pm 0.1$ & $2.5 \pm 0.4^{\mathrm{a}, \mathrm{d}}$ \\
Fasting plasma glucose $(\mathrm{mmol} / \mathrm{l})$ & $4.7 \pm 0.1$ & $5.2 \pm 0.2^{\mathrm{a}}$ & $9.0 \pm 0.7^{\mathrm{b}, \mathrm{d}}$ \\
Fasting plasma insulin $(\mathrm{pmol} / \mathrm{l})$ & $21 \pm 7$ & $49 \pm 7^{\mathrm{a}}$ & $118 \pm 14^{\mathrm{b}, \mathrm{d}}$ \\
HOMA-IR & $0.7 \pm 0.2$ & $1.7 \pm 0.3^{\mathrm{a}}$ & $6.9 \pm 1.0^{\mathrm{b}, \mathrm{d}}$ \\
NEFA $(\mu \mathrm{mol} / \mathrm{l})$ & $0.47 \pm 0.05$ & $0.57 \pm 0.05$ & $0.69 \pm 0.07^{\mathrm{a}}$ \\
TNF- $\alpha(\mathrm{pg} / \mathrm{ml})$ & $0.9 \pm 0.15$ & $0.88 \pm 0.18$ & $1.44 \pm 0.19^{\mathrm{a}, \mathrm{c}}$ \\
\hline
\end{tabular}

during a euglycaemic insulin clamp $(r=-0.519, p<0.01)$ (Table 2). sIL-6R was significantly higher in diabetic patients vs lean NGT individuals $(p<0.01)$ (Fig. 3h). sIL6R levels were inversely and significantly correlated with insulin sensitivity $(r=-0.441, p<0.02$, Table 2$)$. Both increased sTNFR1 and sIL-6R levels significantly correlated with elevated $\mathrm{HbA}_{1 \mathrm{c}}$ levels and BMI (Table 2). No differences in TNFR2, sICAM and sVCAM serum concentrations were observed between lean, obese and diabetic groups, and there were no significant correlations with $\mathrm{BMI}, \mathrm{HbA}_{1 \mathrm{c}}$ and a

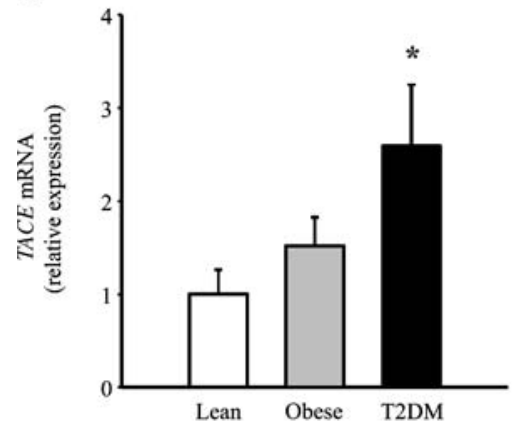

d

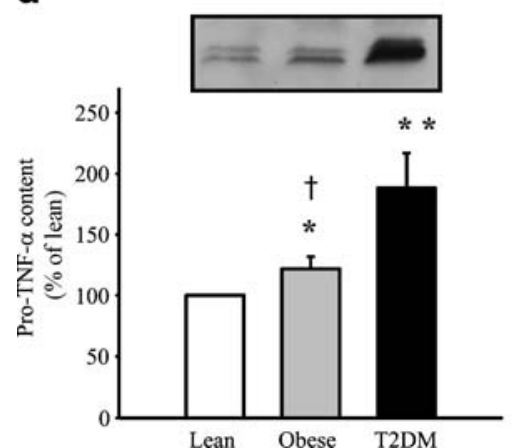

b

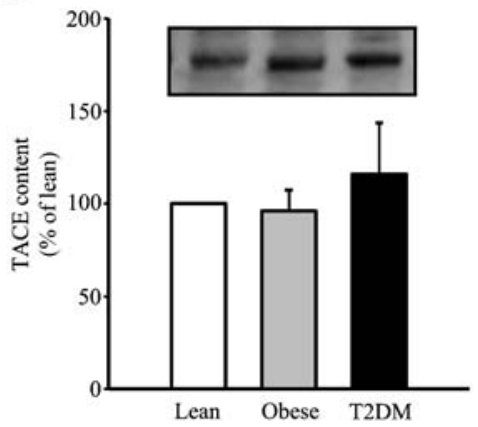

e

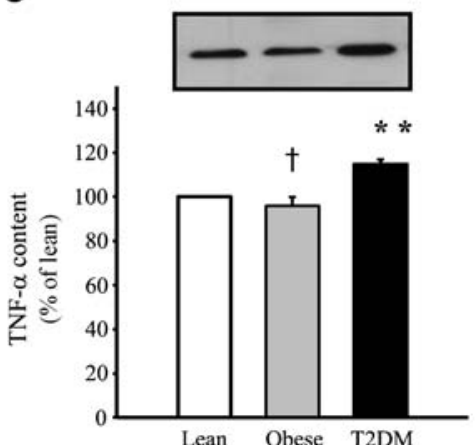

C

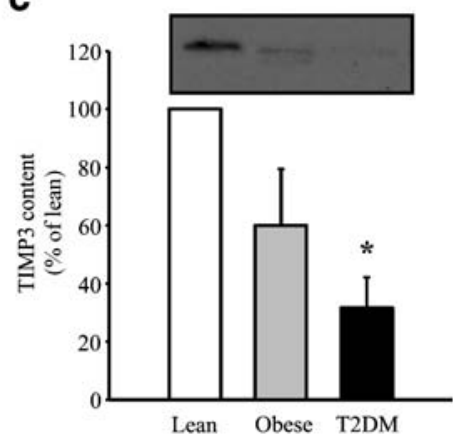

f

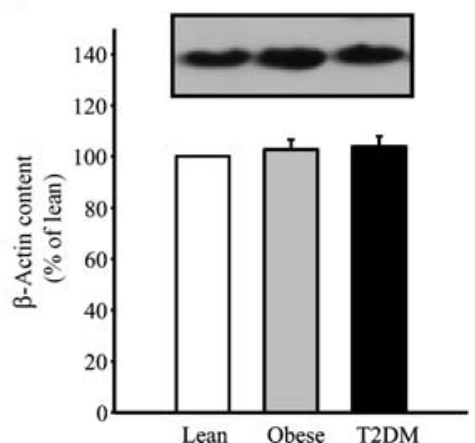

Fig. 2 mRNA for TACE, and TIMP3, pro-TNF- $\alpha$ and TNF- $\alpha$ protein abundance in human skeletal muscle. a Expression of TACE was measured by quantitative real-time RT-PCR and normalised for $18 \mathrm{~S}$ ribosomal RNA in vastus lateralis (skeletal) muscle. Relative quantification was calculated by the $2^{-\Delta \Delta C_{t}}$ where $\Delta C_{t}$ is $C_{t}-18 S$ $\mathrm{C}_{\mathrm{t}}$. Each reaction was done in duplicate. b Western blot analysis of TACE protein in vastus lateralis muscle. Protein was extracted from total homogenate, solubilised and separated on SDS-PAGE, transferred to nitrocellulose membranes and incubated with rabbit polyclonal anti-TACE antibody. Abundance of TIMP3 (c), pro-TNF$\alpha(\mathbf{d})$, TNF- $\alpha$ (e) and $\beta$-actin (f) in vastus lateralis muscle. Data are means \pm SEM. ${ }^{*} p<0.01$ vs lean, ${ }^{* *} p<0.01$ vs lean, ${ }^{\dagger} p<0.05$ vs type 2 diabetes ( $n=10-12$ per group). T2DM, type 2 diabetes mellitus 
Fig. 3 TACE activity in skeletal muscle in vitro and circulating TACE substrates in lean and obese individuals and type 2 diabetes patients. a, b TACE peptide cleavage was measured by a fluorimetric assay with different quantities of skeletal muscle protein: a relative fluorescence units (RFUs; black circles, $1 \mu \mathrm{g}$; white circles, $5 \mu \mathrm{g}$; black inverted triangles, $10 \mu \mathrm{g}$; white triangles, $15 \mu \mathrm{g}$; black squares, $30 \mu \mathrm{g}$ ); b AUCs. c TACE peptide cleavage (RFUs) at $10 \mu \mathrm{g}$ muscle homogenate protein from lean NGT (black circles) and obese NGT individuals (white circles) and type 2 diabetes (T2DM) patients (black inverted triangles). d AUCs for TACE activity in vitro in lean NGT, obese NGT and type 2 diabetes patients. e, f Correlations between $\log _{10}$ TACE activity and NEFA $\left(\mathbf{e}, r=0.460, r^{2}=0.211\right.$, $p=0.05)$ and $\log _{10}$ TACE activity and $\log _{10} M$ (f, $r=0.471$, $\left.r^{2}=0.222, p=0.036\right)$. $\mathbf{g}, \mathbf{h}$ Serum concentration (measured with ELISA) of sTNFR1 (g) and sIL-6R (h) in lean NGT and obese NGT individuals and type 2 diabetic patients. Data are means \pm SEM. $* p<0.05$, $* * p<0.01 \quad(n=20$ for

TACE activity and $8-10$ for sTNFR1 and sIL-6R)
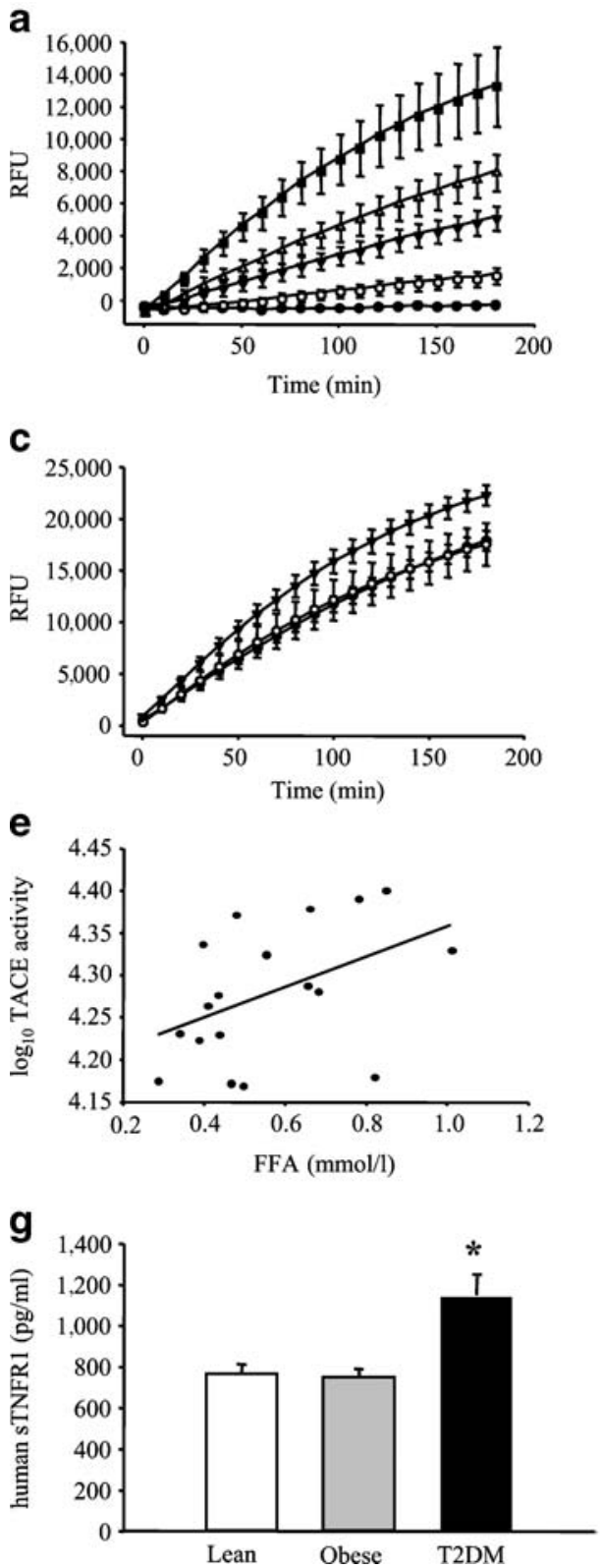
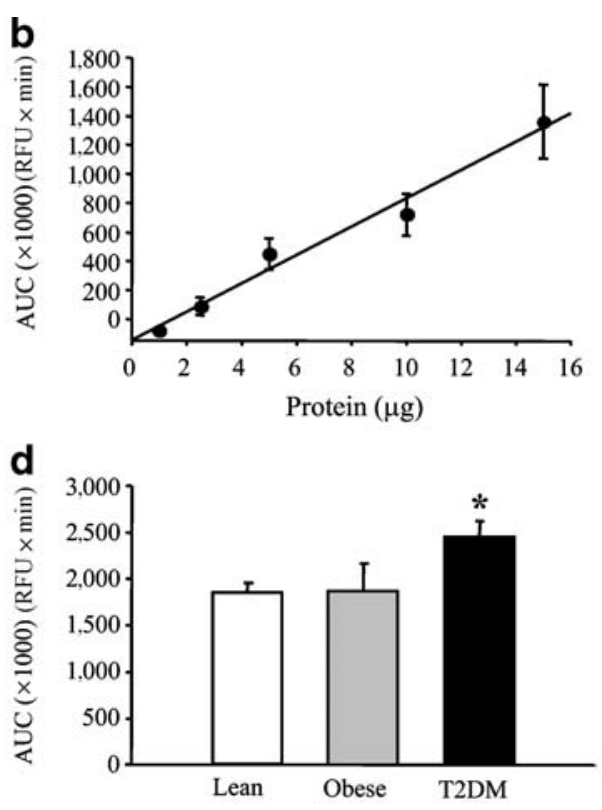

f
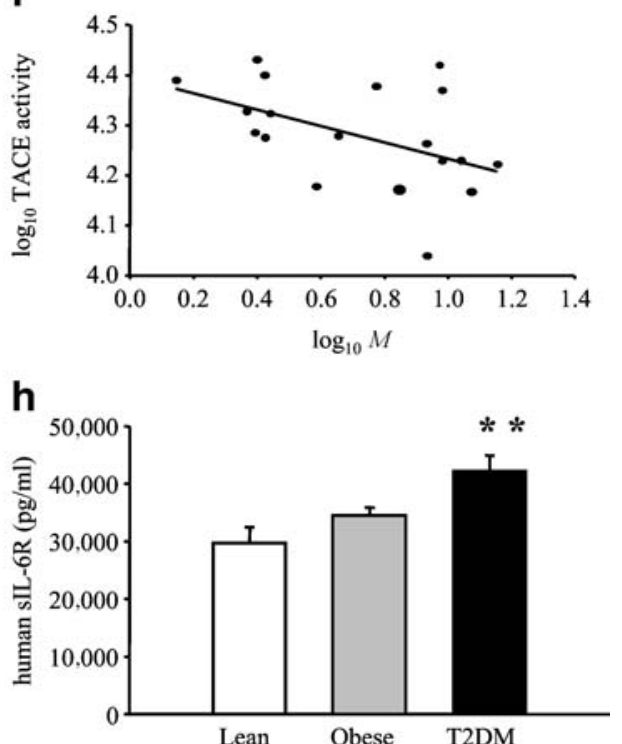

$M$ values (Table 2 and data not shown). In multivariate analysis (Table 3), insulin sensitivity was inversely correlated with TNFR1 and 2 and IL-6R. Altogether, these proinflammatory cytokines explained $46 \%\left(r^{2}=0.457, p=0.02\right)$ of variance in the insulin-mediated rate of glucose uptake. Likewise, when a multivariate was performed with $\mathrm{HbA}_{1 \mathrm{c}}$ as the dependent variable, these inflammatory mediators could explain $72 \%\left(r^{2}=0.719, p<0.0005\right)$ variability in $\mathrm{HbA}_{1 \mathrm{c}}$ concentration. Also, in a multivariate analysis (ESM Table 2), plasma TNF- $\alpha$ was associated with fasting plasma glucose, $\mathrm{HbA}_{1 \mathrm{c}}$, and TNFR1 and 2, and inversely associated with insulin sensitivity. Furthermore, sICAM made an independent contribution to plasma TNF- $\alpha$ concentrations. Altogether these variables explained $67 \%(p=0.02)$ of variance in plasma TNF- $\alpha$ concentrations.
Effect of lipid infusion in TACE/TIMP3 expression Obesity and type 2 diabetes are characterised by increased circulating levels of NEFAs. Lipid infusion acutely raises the plasma and intracellular fatty acid levels, induces insulin resistance and stimulates inflammation in muscle [34-36]. To examine the effect of lipid infusion on TACE and TIMP3 activities, we performed a $6 \mathrm{~h}$ lipid or saline infusion in 12 lean NGT individuals. Lipid infusion increased the plasma NEFA concentration from $618 \pm 80$ to $1,863 \pm 423 \mu \mathrm{mol} / 1$ and markedly decreased insulinstimulated total body glucose disposal by $20 \%(p<0.001)$ (Fig. 4a). After $6 \mathrm{~h}$ of lipid vs saline infusion, TACE expression increased fourfold (Fig. 4b), and TIMP3 expression decreased threefold (Fig. 4c) in skeletal muscle biopsies, while $I R$ expression showed a decrease, although 
Table 2 Correlation of circulating TACE substrates and of NEFA with BMI, $\mathrm{HbA}_{1 \mathrm{c}}$ and $M$ values

\begin{tabular}{|c|c|c|c|c|c|c|}
\hline \multirow[t]{2}{*}{ Substrate } & \multicolumn{2}{|l|}{ BMI } & \multicolumn{2}{|l|}{$\mathrm{HbA}_{1 \mathrm{c}}$} & \multicolumn{2}{|l|}{$M$ value } \\
\hline & $r$ & $p$ value & $r$ & $p$ value & $r$ & $p$ value \\
\hline sTNFR1 & 0.502 & 0.001 & 0.6245 & $<0.0001$ & -0.519 & 0.003 \\
\hline sTNFR2 & 0.2038 & 0.22 & 0.2829 & 0.09 & -0.262 & 0.16 \\
\hline sIL-6R & 0.3406 & 0.04 & 0.3661 & 0.02 & -0.441 & 0.015 \\
\hline sVCAM & 0.1269 & 0.45 & 0.22 & 0.23 & -0.271 & 0.15 \\
\hline sICAM & 0.2347 & 0.16 & 0.058 & 0.75 & -0.215 & 0.25 \\
\hline TNF- $\alpha$ & 0.467 & 0.009 & 0.672 & $<0.001$ & -0.451 & 0.014 \\
\hline NEFA & 0.117 & 0.479 & 0.331 & 0.04 & -0.384 & 0.017 \\
\hline
\end{tabular}

not significant, following lipid infusion (Fig. 4d). Both IRS1 and $A k t$ demonstrated a marked $80 \%$ decrease in RNA levels (Fig. 4e, f). In addition, after $2 \mathrm{~h}$ of lipid infusion, plasma sIL-6R concentration increased 1.3-fold $(p<0.05)$ and remained elevated during the insulin clamp $\left(80 \mathrm{mU} \mathrm{m} \mathrm{m}^{-2} \mathrm{~min}^{-1}\right.$ ) (Fig. $4 \mathrm{~g}$ ). After $6 \mathrm{~h}$ of lipid vs saline infusion, protein levels of IRS-1, AKT, TIMP3 and TACE were unaffected (ESM Fig. 6), suggesting that lipotoxicity may act chronically increasing $T A C E$ expression but also increasing its activity.

Effect of palmitate in TACE/TIMP3 expression in human myotubes To examine further the direct effect of lipotoxicity on TACE activity we incubated human myoblasts from lean NGT individuals with increasing concentrations of palmitate, a saturated fatty acid. In an in vitro set, palmitate produced a modest but statistically significant 12$18 \%$ decrease in TACE protein levels (Fig. 5a) and a dramatic decrease in TIMP3 levels by $\sim 40 \%$ at $200 \mu \mathrm{mol} /$ 1 and $\sim 70 \%$ at $400 \mu \mathrm{mol} / 1$ over a $4 \mathrm{~h}$ time period (Fig. $5 \mathrm{~b}$ ). Therefore, the TACE/TIMP3 stoichiometry was increased from 1.5- to 2.5-fold after palmitate treatment, suggesting that also in this in vitro system the TACE/TIMP3 dyad is overactive, as observed in vivo, both in type 2 diabetic patients and after lipid infusion (Fig. 5c). $\beta$-Actin level was unchanged by palmitate treatment (Fig. 5d). Finally, to look for metabolic effects of TACE activation we infected primary human myotubes with adenovirus encoding $T A C E$ or GFP for control (Fig. 6a). We observed that increased TACE determined a significant increase in pro-TNF- $\alpha$ and TNF- $\alpha$ shedding, mimicking the in vivo situation (Fig. $6 b-d$ ). Increased TNF- $\alpha$ shedding was associated with a significant reduction in insulin-induced phosphorylation of AKT (Fig. 6e, f). By contrast, we did not observe an effect of increased TNF- $\alpha$ shedding on phosphorylation of AMPK and its substrate ACC (Fig. 6g-i). $\beta$-Actin level was similar in both the groups (Fig. 6j).

\section{Discussion}

In humans, skeletal muscle accounts for $60-70 \%$ of glucose uptake in the postprandial period and for $80-90 \%$ of glucose disposal during i.v. glucose/insulin infusion [37, 38]. Therefore, identification of factors that impair muscle glucose uptake in insulin-resistant states, such as obesity and type 2 diabetes, is of great clinical importance. Among the various cytokines synthesised by skeletal muscle under basal conditions and in response to inflammation, TNF- $\alpha$ is of particular relevance because it impedes glucose uptake in human skeletal muscle by inhibiting insulin signal transduction, while concomitantly causing endothelial dysfunction [12, 39-42]. A number of studies, but not all, have demonstrated increased circulating levels of TNF- $\alpha$ and increased mRNA expression in adipose tissue and skeletal
Table 3 Determinants of insulin sensitivity and $\mathrm{HbA}_{1 \mathrm{c}}$

Data are correlation coefficients and their $p$ values in multivariate models with insulin sensitivity ( $M$ value) and $\mathrm{HbA}_{1 \mathrm{c}}$ as the dependent variables

\begin{tabular}{|c|c|c|c|c|}
\hline \multirow[t]{2}{*}{ Variable } & \multicolumn{2}{|c|}{$M$ value } & \multicolumn{2}{|l|}{$\mathrm{HbA}_{1 \mathrm{c}}$} \\
\hline & $r$ & $p$ value & $r$ & $p$ value \\
\hline TNF- $\alpha$ & -0.451 & 0.007 & 0.672 & $<0.0005$ \\
\hline sTNFR1 & -0.516 & 0.002 & 0.656 & $<0.0005$ \\
\hline sTNFR2 & -0.309 & 0.05 & 0.399 & 0.02 \\
\hline sIL-6R & -0.401 & 0.02 & 0.373 & NS \\
\hline sVCAM & -0.241 & NS & 0.201 & NS \\
\hline sICAM & -0.246 & NS & 0.07 & NS \\
\hline Total explained variance $(\%)$ & 46 & & 71 & \\
\hline
\end{tabular}


a

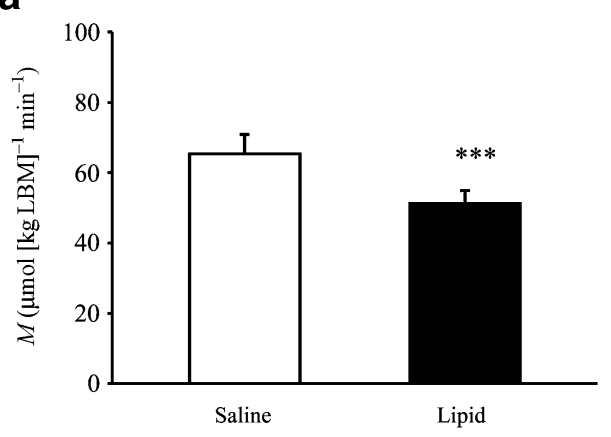

C

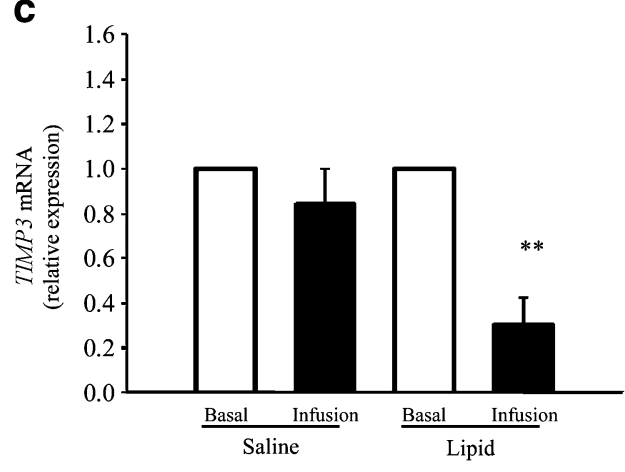

b

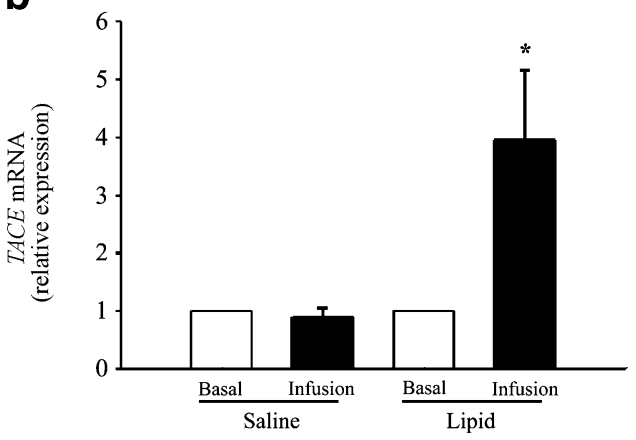

d

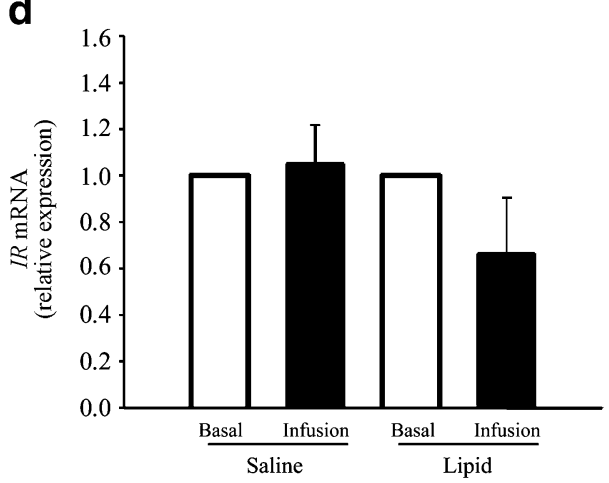

e

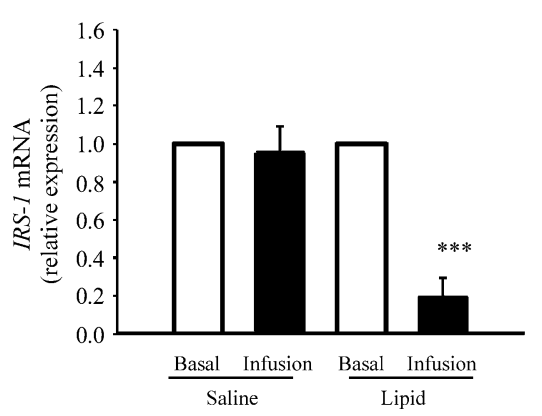

f

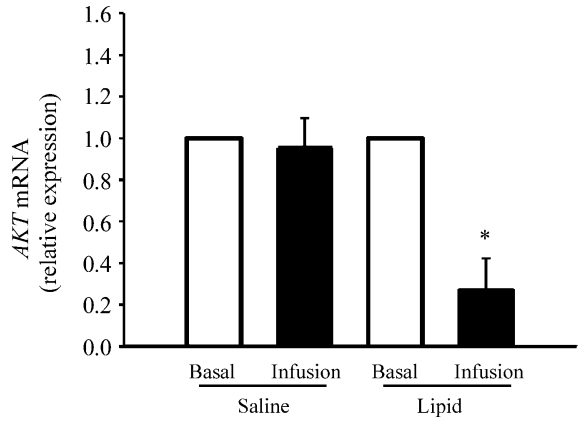

g

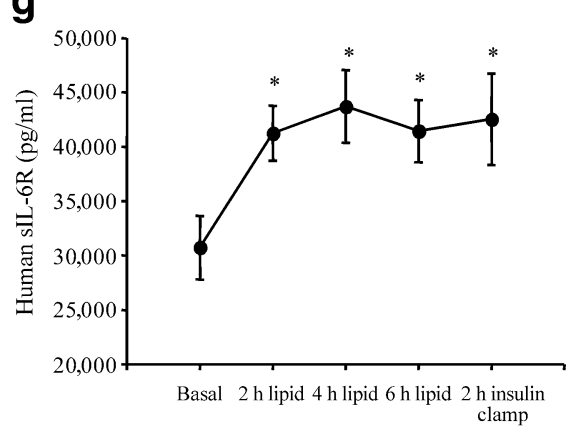

Fig. 4 a Insulin-stimulated glucose metabolism ( $M$ value) was measured with the euglycaemic insulin clamp during saline and lipid infusion. b-f mRNA expression for TACE (b), TIMP3 (c), IR (d), IRS-1 (e) and $A K T$ (f) was measured in human vastus lateralis (skeletal) muscle before and after a $6 \mathrm{~h}$ lipid or saline infusion in lean NGT

muscle of obese and insulin-resistant humans [13, 39-44]. A large body of evidence documents that adipose tissue is an active endocrine organ that secretes multiple proteins to modulate insulin sensitivity in muscle/liver and intracellular pathways involved in inflammation and atherosclerosis [45]. An emerging concept is that the differential localisation and release of TNF- $\alpha$ in individual tissues could be a critical determinant of insulin resistance.

In animal models, it is generally accepted that circulating TNF- $\alpha$ levels may not reflect autocrine or paracrine action of the cytokine [10]. In adipose tissue, membraneassociated TNF- $\alpha$ acts locally to inhibit adipogenesis through TNFR1 [46]. In mice, this could, in part, be individuals. $\mathrm{g}$ Serum concentrations of sIL-6R before and after a $2-6 \mathrm{~h}$ lipid infusion, and after a $2 \mathrm{~h}$ euglycaemic insulin $80 \mathrm{mU} \mathrm{m}^{-2} \mathrm{~min}^{-1}$ clamp. Data are means \pm SEM. ${ }^{*} p<0.05,{ }^{* *} p<0.01,{ }^{* * *} p<0.001$, all compared with basal ( $n=10-12$ individuals per group). LBM, lean body mass

explained by the low levels of Tace expression in adipose tissue compared with skeletal muscle (M. Federici, unpublished data). In rats, both membrane-associated and soluble $\mathrm{TNF}-\alpha$ are present in adipose tissue, while in skeletal muscle soluble TNF- $\alpha$ is predominant [10]. Consistent with this, antibody neutralisation of circulating TNF- $\alpha$ increases glucose transport in muscle but not in adipose tissue [47]. If TNF- $\alpha$ acts in a paracrine or autocrine fashion, rather than in an endocrine fashion, this could explain the ineffectiveness of TNF- $\alpha$-neutralising antibody treatment in humans [15], and some reports in type 2 diabetic patients with insulin resistance but not showing elevated plasma TNF- $\alpha$ levels [44]. Here we have demonstrated by confocal 
Fig. 5 Expression in human myotubes of TACE (a), TIMP3 (b), TACE/TIMP3 ratio (c) and $\beta$-actin (d). * $p<0.05,200$ $\mu \mathrm{mol} / 1$ NEFA vs BSA control (BSA-Ctrl); $* * p<0.05$, $400 \mu \mathrm{mol} / 1 \mathrm{NEFA}$ vs BSA. ${ }^{\dagger} p<0.05,200 \mu \mathrm{mol} / 1$ NEFA vs $400 \mu \mathrm{mol} / 1$ NEFA. $n=4-6$ per group. Data are means \pm SEM a

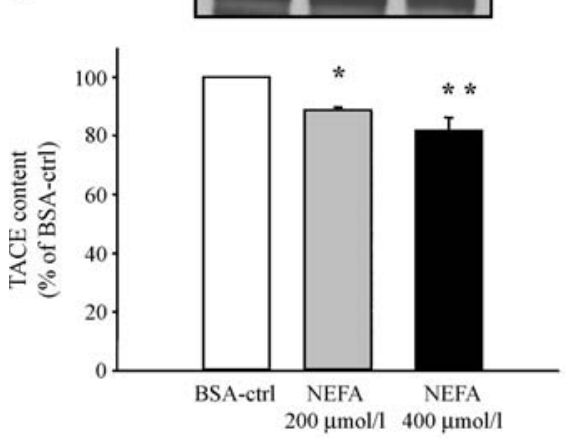

C

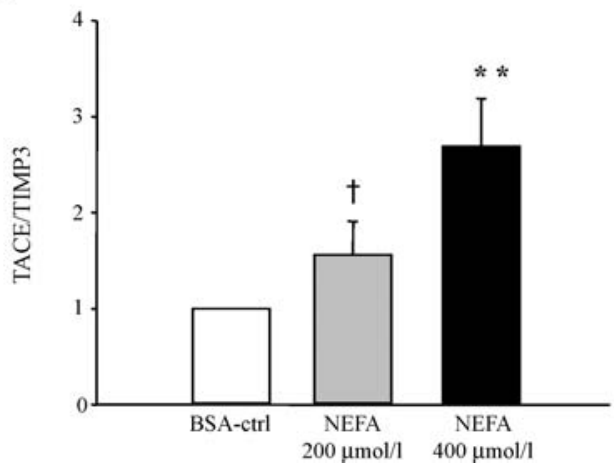

b

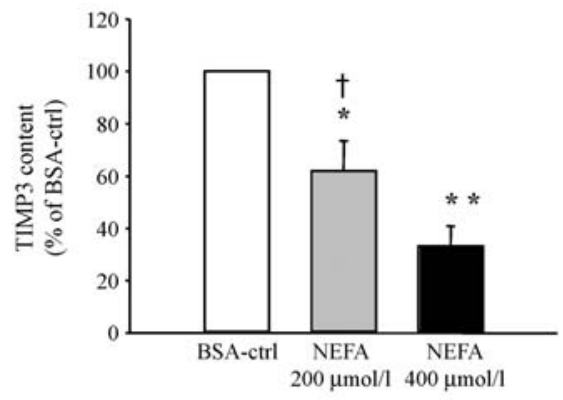

d

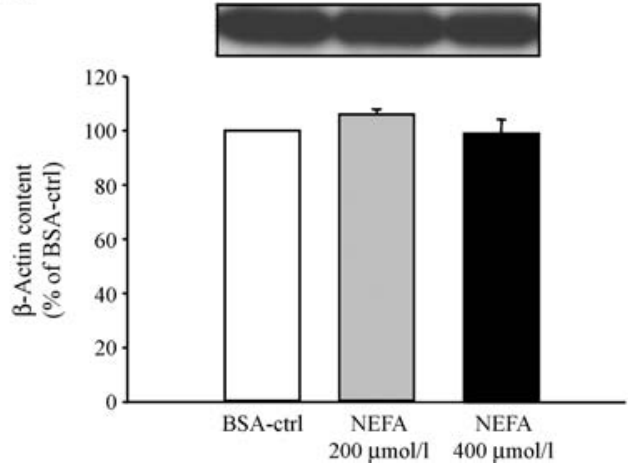

microscopy and tissue subcellular fractionation that TACE, TIMP3, TNF- $\alpha$ and IR are co-produced in the sarcolemma and this is contributing to the novel concept that locally generated TNF- $\alpha$ exerts paracrine effects to inhibit insulin signalling.

The paracrine effect of TNF- $\alpha$ is dependent on the reciprocal interaction between the stimulatory action of TACE or ADAM-17 and its endogenous inhibitor TIMP3. Recent evidence from animal models show that the actions of TNF- $\alpha$ on inflammation and metabolism are regulated through the TIMP3/TACE dyad [20, 21, 42, 48].

The current study is the first to show in humans that insulin-resistant conditions, such as obesity and type 2 diabetes, are associated with elevated TACE activity in human skeletal muscle, while TIMP3 is diminished. These data are consistent with the hypothesis that TIMP3 downregulation leads to an increase in TACE activity and an augmented release of TNF- $\alpha$. Our study also shows that other specific TACE substrates like sIL-6R and TNFR1 are differentially shed in diabetes and insulin resistance. Also, we have shown for the first time in humans the relative contribution of fasting plasma glucose, $\mathrm{HbA}_{1 \mathrm{c}}$ and insulin sensitivity to circulating plasma TNF- $\alpha$ concentrations. Given the cross-sectional nature of the present study, it is not possible to determine whether elevated plasma TNF- $\alpha$ is a primary or secondary phenomenon. One could speculate that obesity leads to elevated TNF- $\alpha$, which in turn can lead to systemic insulin resistance and hyperglycaemia. On the other hand, it is possible that hyper- glycaemia and insulin resistance per se could lead to elevated TNF- $\alpha$ concentration.

Short lipid infusion leads to a physiological elevation in plasma NEFA concentrations, and causes insulin resistance in skeletal muscle and liver [35, 49]. Therefore, we examined whether lipid infusion in lean healthy NGT individuals would cause an inversion in TACE/TIMP3 ratio resulting in increased TACE activity. As previously shown, a short-term elevation of the plasma NEFA concentration caused marked insulin resistance in the skeletal muscle [35], and we now demonstrate reciprocal regulation of considerable magnitude of TACE and TIMP3 expression with increased TACE and decreased TIMP3 gene expression of fourfold and threefold, respectively (Fig. 4). Furthermore, within $2 \mathrm{~h}$ of the start of lipid infusion, sIL-6R increased 1.3-fold, indicating that the change in $T A C E$ expression was associated with an increase in TACE activity (Fig. 4). In keeping with our in vivo observations, we found in vitro that palmitate caused an imbalance in TACE/TIMP 3 ratio that could favour increased TNF- $\alpha$ shedding. NEFAs are known to cause insulin resistance and induce TNF- $\alpha$ secretion as a result of JNK activation via a paracrine modality, in cell culture studies [50], while treatment of $\mathrm{C} 2 \mathrm{C} 12$ mouse myoblasts with palmitate leads to increased TACE activity (M. Federici, unpublished data). To understand whether increased TACE activity directly impaired insulin metabolic actions we analysed primary myotubes infected with TACE, finding a significant decrease in AKT phosphorylation, a major contributor to 

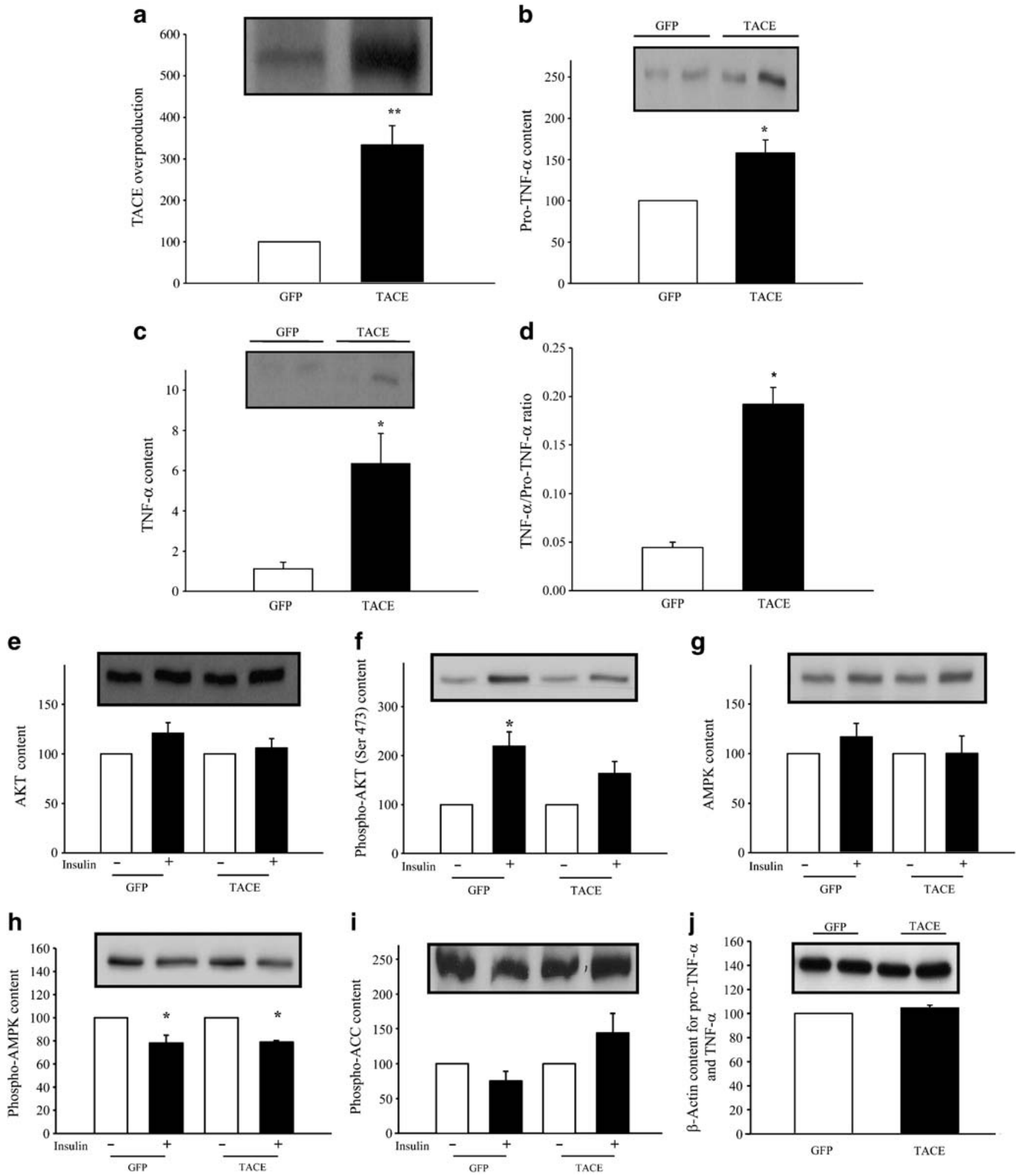

Fig. 6 a TACE levels in human myotubes infected with adenovirus encoding TACE or GFP for control. b-d Increased TNF- $\alpha$ shedding in the presence of increased abundance of both pro-TNF- $\alpha$ and TNF- $\alpha$. e, f AKT and phospho-AKT (Ser 473) levels in myotubes in the presence $(+)$ and absence $(-)$ of insulin $(10 \mathrm{nmol} / \mathrm{l})$. g, h AMPK and phospho-AMPK levels in the presence $(+)$ and absence $(-)$ of insulin.

i Phospho-ACC levels in human myotubes in the presence $(+)$ or absence ( - ) of insulin. ${ }^{*} p<0.05$ vs GFP and absence of insulin; ${ }^{*} p<<$ 0.01 vs GFP. $n=4-6$ per group. Data are means \pm SEM. $\mathbf{j} \beta$-Actin as a protein loading control for pro-TNF- $\alpha$ and TNF- $\alpha$ levels. $n=4$ per group. Data are means \pm SEM. Values are expressed as a percentage of control 
regulation of insulin metabolic actions. In summary, our results show that local generation of $\mathrm{TNF}-\alpha$ in skeletal muscle via the TIMP3/TACE dyad contributes to the pathogenesis of insulin resistance in type 2 diabetic obese patients. We propose that local targeting of this pathway represents a novel pharmacological approach to the inhibition of inflammation and reversal of insulin resistance.

Acknowledgements This study was supported by start-up funds to F. Folli from the UTHSCSA. R. A. DeFronzo was supported by an NIH grant, Regulation of Hepatic and Peripheral Glucose Metabolism (RO1DK024092), and a VA Merit Award, Molecular Epidemiology of Type 2 Diabetes Mellitus in Mexican Americans. Images were generated in the Core Optical Imaging Facility, which is supported by UTHSCSA, NIH-NCI P30 CA54174 (San Antonio Cancer Institute), NIH-NIA P30 AG013319 (Nathan Shock Center) and (NIH-NIA P01AG19316). A. Monroy and A. O. Chavez were supported by a Minority (A. Monroy) and Mentor-Based (A. O. Chavez) Postdoctoral Fellowships from the American Diabetes Association awarded to R. A. DeFronzo. We thank M. Palomo and K. Delgado for outstanding assistance throughout the studies.

Duality of interest The authors declare that there is no duality of interest associated with this manuscript.

\section{References}

1. DeFronzo RA (2004) Pathogenesis of type 2 diabetes mellitus. Med Clin North Am 88:787-835

2. Shoelson SE, Lee J, Goldfine AB (2006) Inflammation and insulin resistance. J Clin Invest 116:1793-1801

3. Van Gaal LF, Mertens IL, de Block CE (2006) Mechanisms linking obesity with cardiovascular disease. Nature 444:875-880

4. Hotamisligil GS, Shargill NS, Spiegelman BM (1993) Adipose expression of tumor necrosis factor-alpha: direct role in obesitylinked insulin resistance. Science 259:87-91

5. Rui L, Aguirre V, Kim JK et al (2001) Insulin/IGF-1 and TNFalpha stimulate phosphorylation of IRS-1 at inhibitory Ser307 via distinct pathways. J Clin Invest 107:181-189

6. Peraldi P, Hotamisligil GS, Buurman WA, White MF, Spiegelman BM (1996) Tumor necrosis factor (TNF)-alpha inhibits insulin signaling through stimulation of the p55 TNF receptor and activation of sphingomyelinase. J Biol Chem 271:13018-13022

7. Hotamisligil GS, Peraldi P, Budavari A, Ellis R, White MF, Spiegelman BM (1996) IRS-1-mediated inhibition of insulin receptor tyrosine kinase activity in TNF-alpha- and obesityinduced insulin resistance. Science 271:665-668

8. Kahn CR, Neville DM Jr, Roth J (1973) Insulin-receptor interaction in the obese-hyperglycemic mouse. A model of insulin resistance. J Biol Chem 248:244-250

9. Folli F, Saad MJ, Backer JM, Kahn CR (1993) Regulation of phosphatidylinositol 3-kinase activity in liver and muscle of animal models of insulin-resistant and insulin-deficient diabetes mellitus. J Clin Invest 92:1787-1794

10. Borst SE, Conover CF (2005) High-fat diet induces increased tissue expression of TNF-alpha. Life Sci 77:2156-2165

11. Csehi SB, Mathieu S, Seifert U et al (2005) Tumor necrosis factor (TNF) interferes with insulin signaling through the p55 TNF receptor death domain. Biochem Biophys Res Commun 329:397405

12. Katsuki A, Sumida Y, Murashima S et al (1998) Serum levels of tumor necrosis factor-alpha are increased in obese patients with noninsulin-dependent diabetes mellitus. J Clin Endocrinol Metab 83:859-862

13. Miyazaki Y, Pipek R, Mandarino LJ, DeFronzo RA (2003) Tumor necrosis factor alpha and insulin resistance in obese type 2 diabetic patients. Int J Obes Relat Metab Disord 27:88-94

14. Cardellini M, Perego L, D'Adamo $M$ et al (2005) C-174G polymorphism in the promoter of the interleukin-6 gene is associated with insulin resistance. Diabetes Care 28:2007-2012

15. Ofei F, Hurel S, Newkirk J, Sopwith M, Taylor R (1996) Effects of an engineered human anti-TNF-alpha antibody (CDP571) on insulin sensitivity and glycemic control in patients with NIDDM. Diabetes 45:881-885

16. Black RA, Rauch CT, Kozlosky CJ et al (1997) A metalloproteinase disintegrin that releases tumour-necrosis factoralpha from cells. Nature 385:729-733

17. Moss ML, Jin SL, Milla ME et al (1997) Cloning of a disintegrin metalloproteinase that processes precursor tumour-necrosis factoralpha. Nature 385:733-736

18. Mohammed FF, Smookler DS, Taylor SE et al (2004) Abnormal TNF activity in Timp3-/- mice leads to chronic hepatic inflammation and failure of liver regeneration. Nat Genet 36:969-977

19. Amour A, Slocombe PM, Webster A et al (1998) TNF-alpha converting enzyme (TACE) is inhibited by TIMP-3. FEBS Lett 435:39-44

20. Federici M, Hribal ML, Menghini R et al (2005) Timp3 deficiency in insulin receptor-haploinsufficient mice promotes diabetes and vascular inflammation via increased TNF-alpha. J Clin Invest 115:3494-3505

21. Serino M, Menghini R, Fiorentino L et al (2007) Mice heterozygous for tumor necrosis factor-alpha converting enzyme are protected from obesity-induced insulin resistance and diabetes. Diabetes 56:2541-2546

22. Gelling RW, Yan W, Al-Noori S et al (2008) Deficiency of TNFalpha converting enzyme (TACE/ADAM17) causes a lean, hypermetabolic phenotype in mice. Endocrinology 149:60536064

23. World Health Organization (1999) Definition, diagnosis and classification of diabetes mellitus and its complications: report of a WHO consultation. Part 1: diagnosis and classification of diabetes mellitus. World Health Organization, Geneva

24. DeFronzo RA, Tobin JD, Andres R (1979) Glucose clamp technique: a method for quantifying insulin secretion and resistance. Am J Physiol 237:E214-E223

25. Matthews DR, Hosker JP, Rudenski AS, Naylor BA, Treacher DF, Turner RC (1985) Homeostasis model assessment: insulin resistance and beta-cell function from fasting plasma glucose and insulin concentrations in man. Diabetologia 28:412-419

26. Bolte S, Cordelieres FP (2006) A guided tour into subcellular colocalization analysis in light microscopy. J Microsc 224:213232

27. Li Q, Lau A, Morris TJ, Guo L, Fordyce CB, Stanley EF (2004) A syntaxin 1, Galpha(o), and N-type calcium channel complex at a presynaptic nerve terminal: analysis by quantitative immunocolocalization. J Neurosci 24:4070-4081

28. Nori A, Lin PJ, Cassetti A, Villa A, Bayer KU, Volpe P (2003) Targeting of alpha-kinase-anchoring protein (alpha KAP) to sarcoplasmic reticulum and nuclei of skeletal muscle. Biochem J 370:873-880

29. Ostrowski J, Klimek-Tomczak K, Wyrwicz LS, Mikula M, Schullery DS, Bomsztyk K (2004) Heterogeneous nuclear ribonucleoprotein $\mathrm{K}$ enhances insulin-induced expression of mitochondrial UCP2 protein. J Biol Chem 279:54599-54609

30. Chavez AO, Lopez-Alvarenga JC, Tejero ME et al (2008) Physiological and molecular determinants of insulin action in the baboon. Diabetes 57:899-908 
31. Zhan M, Jin B, Chen SE, Reecy JM, Li YP (2007) TACE release of TNF-alpha mediates mechanotransduction-induced activation of p38 MAPK and myogenesis. J Cell Sci 120:692-701

32. Henry RR, Abrams L, Nikoulina S, Ciaraldi TP (1995) Insulin action and glucose metabolism in nondiabetic control and NIDDM subjects. Comparison using human skeletal muscle cell cultures. Diabetes 44:936-946

33. Reyna SM, Ghosh S, Tantiwong P et al (2008) Elevated toll-like receptor 4 expression and signaling in muscle from insulinresistant subjects. Diabetes 57:2595-2602

34. Itani SI, Ruderman NB, Schmieder F, Boden G (2002) Lipidinduced insulin resistance in human muscle is associated with changes in diacylglycerol, protein kinase $\mathrm{C}$, and IkappaB-alpha. Diabetes 51:2005-2011

35. Belfort R, Mandarino L, Kashyap S et al (2005) Dose-response effect of elevated plasma free fatty acid on insulin signaling. Diabetes 54:1640-1648

36. Mohlig M, Freudenberg M, Bobbert T et al (2006) Acetylsalicylic acid improves lipid-induced insulin resistance in healthy men. $\mathrm{J}$ Clin Endocrinol Metab 91:964-967

37. DeFronzo RA (1988) Lilly lecture, 1987. The triumvirate: betacell, muscle, liver. A collusion responsible for NIDDM. Diabetes 37:667-687

38. DeFronzo RA, Jacot E, Jequier E, Maeder E, Wahren J, Felber JP (1981) The effect of insulin on the disposal of intravenous glucose. Results from indirect calorimetry and hepatic and femoral venous catheterization. Diabetes 30:1000-1007

39. del Aguila LF, Claffey KP, Kirwan JP (1999) TNF-alpha impairs insulin signaling and insulin stimulation of glucose uptake in C2C12 muscle cells. Am J Physiol 276:E849-E855

40. Krogh-Madsen R, Plomgaard P, Moller K, Mittendorfer B, Pedersen BK (2006) Influence of TNF-alpha and IL-6 infusions on insulin sensitivity and expression of IL-18 in humans. Am J Physiol Endocrinol Metab 291:E108-E114
41. Saghizadeh M, Ong JM, Garvey WT, Henry RR, Kern PA (1996) The expression of TNF alpha by human muscle. Relationship to insulin resistance. J Clin Invest 97:1111-1116

42. Tang ZY, Loss G, Carmody I, Cohen AJ (2006) TIMP-3 ameliorates hepatic ischemia/reperfusion injury through inhibition of tumor necrosis factor-alpha-converting enzyme activity in rats. Transplantation 82:1518-1523

43. Reid MB, Li YP (2001) Cytokines and oxidative signalling in skeletal muscle. Acta Physiol Scand 171:225-232

44. Carey AL, Bruce CR, Sacchetti M et al (2004) Interleukin-6 and tumor necrosis factor-alpha are not increased in patients with Type 2 diabetes: evidence that plasma interleukin-6 is related to fat mass and not insulin responsiveness. Diabetologia 47:1029-1037

45. Hotamisligil GS (2006) Inflammation and metabolic disorders. Nature 444:860-867

46. Xu H, Sethi JK, Hotamisligil GS (1999) Transmembrane tumor necrosis factor (TNF)-alpha inhibits adipocyte differentiation by selectively activating TNF receptor 1 . J Biol Chem 274:2628726295

47. Borst SE, Lee Y, Conover CF, Shek EW, Bagby GJ (2004) Neutralization of tumor necrosis factor-alpha reverses insulin resistance in skeletal muscle but not adipose tissue. Am J Physiol Endocrinol Metab 287:E934-E938

48. Smookler DS, Mohammed FF, Kassiri Z, Duncan GS, Mak TW, Khokha R (2006) Tissue inhibitor of metalloproteinase 3 regulates TNF-dependent systemic inflammation. J Immunol 176:721-725

49. Bajaj M, Berria R, Pratipanawatr T et al (2002) Free fatty acidinduced peripheral insulin resistance augments splanchnic glucose uptake in healthy humans. Am J Physiol Endocrinol Metab 283: E346-E352

50. Nguyen MT, Satoh H, Favelyukis S et al (2005) JNK and tumor necrosis factor-alpha mediate free fatty acid-induced insulin resistance in 3T3-L1 adipocytes. J Biol Chem 280:35361-35371 